\title{
Publisher Correction: Pairwise library screen systematically interrogates Staphylococcus aureus Cas9 specificity in human cells
}

\author{
Josh Tycko (1) 1,5, Luis A. Barrera1,6, Nicholas C. Huston 1,7, Ari E. Friedland', Xuebing Wu², \\ Jonathan S. Gootenberg $\mathbb{D}^{3}$, Omar O. Abudayyeh ${ }^{4}$, Vic E. Myer ${ }^{1}$, Christopher J. Wilson $\mathbb{D}^{1}$ \& Patrick D. Hsu ${ }^{1,8}$
}

Correction to: Nature Communications; https://doi.org/10.1038/s41467-018-05391-2; published online 27 July 2018

The original HTML version of this Article incorrectly listed an affiliation of Josh Tycko as 'Department of Genetics, Stanford University School of Medicine, Stanford, CA 94305, USA', instead of the correct 'Present address: Department of Genetics, Stanford University School of Medicine, Stanford, CA 94305, USA'. It also incorrectly listed an affiliation of this author as 'Present address: Arrakis Therapeutics, 35 Gatehouse Dr., Waltham, MA, 02451, USA'.

The original HTML version incorrectly listed an affiliation of Luis A. Barrera as 'Present address: Department of Molecular Biophysics and Biochemistry, Yale University, New Haven, CT, 06511, USA', instead of the correct 'Present address: Arrakis Therapeutics, 35 Gatehouse Dr., Waltham, MA 02451, USA'.

Finally, the original HTML version incorrectly omitted an affiliation of Nicholas C. Huston: 'Present address: Department of Molecular Biophysics and Biochemistry, Yale University, New Haven, CT 06511, USA'.

This has been corrected in the HTML version of the Article. The PDF version was correct from the time of publication.

Published online: 28 August 2018

(i) Open Access This article is licensed under a Creative Commons Attribution 4.0 International License, which permits use, sharing, adaptation, distribution and reproduction in any medium or format, as long as you give appropriate credit to the original author(s) and the source, provide a link to the Creative Commons license, and indicate if changes were made. The images or other third party material in this article are included in the article's Creative Commons license, unless indicated otherwise in a credit line to the material. If material is not included in the article's Creative Commons license and your intended use is not permitted by statutory regulation or exceeds the permitted use, you will need to obtain permission directly from the copyright holder. To view a copy of this license, visit http://creativecommons.org/licenses/by/4.0/.

(C) The Author(s) 2018

\footnotetext{
${ }^{1}$ Editas Medicine, 11 Hurley St., Cambridge, MA 02141, USA. ${ }^{2}$ Whitehead Institute for Biomedical Research, Cambridge, MA 02142, USA. ${ }^{3}$ Department of Systems Biology, Harvard, Cambridge, MA 02138, USA. ${ }^{4}$ Department of Health Sciences and Technology, Massachusetts Institute of Technology, Cambridge, MA 02139, USA. ${ }^{5}$ Present address: Department of Genetics, Stanford University School of Medicine, Stanford, CA 94305, USA. ${ }^{6}$ Present address: Arrakis Therapeutics, 35 Gatehouse Dr., Waltham, MA 02451, USA. ${ }^{7}$ Present address: Department of Molecular Biophysics and Biochemistry, Yale University, New Haven, CT 06511, USA. ${ }^{8}$ Present address: Laboratory of Molecular and Cell Biology, Salk Institute for Biological Studies, La Jolla, CA 92037, USA. Correspondence and requests for materials should be addressed to C.J.W. (email: christopher.wilson@editasmed.com) or to P.D.H. (email: patrick@salk.edu)
} 